\title{
Illustrations
}

TABLES

2.I. Enrollment in the Mutual School of Algiers, November 15, I $838 \quad 62$

3.I. Strength of the Arab Bureaux, I84I-I88I 80

3.2. First- and Second-Class Bureaux, I 847 and I $8648 I$

3.3. Cover Sheet for Annual Statistical Report, Circle of Biskra, August I844 83

4.I. Indigenous Primary Schools and Students in Algiers, I $837-$ I $850 \quad 99$

4.2. Indigenous Schools and Students in Constantine, I837 and I847 100

4.3. Annual Percentage Changes in Total European Population, Public Ownership of Productive Lands, and Hectares per Capita, I $844-$ I 850 IOI

5.I. Sample Entries in Bureau Inspection Reports on Muslim Schools 148

5.2. Instructors in the Circle of Teniet el-Had, April and July I 858 : Age, Familial Status, and Number of Students 152

5.3. Findings of the Bresnier Inquiry of March 25, I858 153

6.I. French Civilians in Proportion to the Total European Population of Algeria, I836-I86I I72

6.2. Placement of Native Graduates of the Imperial Arab-French College of Algiers, I865 and I866 I92

6.3. Distribution of Grants in the École Normale Primaire d'Alger $\quad 193$

6.4. Arab-French Schools, I850-I873 196

6.5. Annual School Inspection Report from the Circle of Laghouat, December 19, I865 198 
FIGURES

2.I. Muslim Population of French Algeria, I830-I872 (in millions) 66 3.I. Government General of Algeria, I834-I867: Structural Organization and Chain of Command 78

3.2. Military Administration of Arab Affairs, I $867-\mathrm{I} 87088$

6.I. Muslim Schools Inspected by the Arab Bureaux, I848-I870 195

\section{A P S}

2.I. Ottoman Regency of Algiers 44

4.I. French Colonial Expansion, I830-1870 105 